\title{
On-line Monitoring of Electrical Equipment and Fault Diagnosis Analysis
}

\author{
Zhao Jian-wei \\ Department of Computer and Information Engineering, Baoding Vocational and Technical College, \\ Baoding, China \\ 50968998@qq.com
}

\begin{abstract}
Keywords: On-line monitoring; Fault diagnosis; Potential transformer; BP neural network.
Abstract. In order to improve the reliability of power system, on-line monitoring and fault diagnosis for electrical equipment is very necessary. In this paper, we research on-line monitoring and fault diagnosis of transformer, building the gas online monitoring system in transformer oil, and improved transformer fault diagnosis -characteristic gas method through the BP neural network. Through gas on-line monitoring of transformer oil, and the example verification, improved diagnosis method is effective for transformer fault diagnosis.
\end{abstract}

\section{Introduction}

With the development of society and economy, the position of the power system has become more important in national economy, therefore the higher safety and reliability on power system are required. At the same time, the reform of the power system also prompted to achieve the ultimate goal that is each power operator hopes using the lowest cost to meet the quality requirements. Taking the scientific means of monitoring and fault diagnosis for electrical equipment for maintenance is the important measures. So that they can find any hidden danger early, then to improve the reliability of equipment, and reduce the cost of operation and maintenance.

Beginning the 60s, every developed country attaches great importance to research the technology about electrical equipment condition monitoring and fault diagnosis. In April 1967, the mechanical failure prevention group was formed by the U.S. navy lab with NASA's guide. In 1976, American Westinghouse development power plant equipment diagnosis system based on the computer. In the 80s, the company shows diagnosis system of generator in the power sector based on a microprocessor. European equipment diagnosis technology research and development of some industrial countries have made progress, and each has its own expertise and characteristics. Equipment diagnosis technology research and development in our country started from the late $70 \mathrm{~s}$, starting in the $80 \mathrm{~s}$, domestic colleges and universities, scientific research and so on to carry out the development of electric power equipment diagnosis technology, developed and made a number of results. In addition, artificial intelligent diagnosis technology is gradually applied in the fault diagnosis of power equipment [1].

Application practice at home and abroad shows that the condition monitoring and fault diagnosis system can reply the real-time control of electrical equipment running status and the characteristics of electrical parameters. So, the occurrence of sudden failure will be reduced, and equipment reliability and operational efficiency will be improved. In the ending, we prolong the service life of equipment, and increase the economic benefit of power system through reduce equipment forced down rate and maintenance cost and life cycle cost. Due to transformer is the most important equipment in power transmission and transformation system, its running reliability directly affects the safety of the power system, the operation cost and economic benefit. Therefore, in this paper, the transformer on-line monitoring and fault diagnosis is studied.

\section{Transformer fault diagnosis}

The principle of transformer fault diagnosis. Due to many types of transformer fault, complex reasons and fault types which may also convert, sometimes it needs various tests and comprehensive 
analysis to accurately determine fault type, degree, position and reason. Although the evaluation of transformer needs all sorts of results, but the DGA (dissolved gas analysis) find equipment failure situation in a timely and effective manner when it is charged, so it has become one of the effective methods of improving the operation reliability of oil filled equipment and putting an end to burning accident.

The principle of transformer fault diagnosis is as follows: when the normal operation of transformer, because of the influence of electricity and heat its insulation oil and organic insulating material will be aging gradually and decompose a small amount of low molecular hydrocarbons and carbon monoxide, carbon dioxide and other gases. As local overheating, internal partial discharge and arc discharge failure, the gas generation rate will accelerate and the number will increase. The gas from the oil will form bubble and constantly dissolve in oil in the process of oil convection and diffusion. When transformer serious accident occurs, gas production rate is greater than the amount of dissolved. Then there is a part of the gas into the gas relay, when accumulated to a certain amount, the gas relay will take action. By relay internal gas analysis and simulation experiment, we will find that gas composition and gas volume of different fault properties and different severity are also different. The main gases which can be used to judge transformer latent fault have hydrogen $\left(\mathrm{H}_{2}\right)$, methane $\left(\mathrm{CH}_{4}\right)$, ethane $\left(\mathrm{C}_{2} \mathrm{H}_{6}\right)$, ethylene $\left(\mathrm{C}_{2} \mathrm{H}_{4}\right)$, acetylene $\left(\mathrm{C}_{2} \mathrm{H}_{2}\right)$, carbon monoxide $(\mathrm{CO})$ and carbon dioxide $\left(\mathrm{CO}_{2}\right)$. The meaning of each gas to judge fault is not the same, but contact with each other. Total hydrocarbon refers to methane, ethane, ethylene and acetylene.

The method of transformer fault diagnosis (characteristic gas method). When the normal operation of transformer, the insulating oil in the process of aging will mainly produce $\mathrm{CO}$ and $\mathrm{CO}_{2}$. When there is partial discharge in oil paper insulation, oil cracking will mainly produce $\mathrm{H}_{2}$ and $\mathrm{CH}_{4}$. When the fault temperature is not much higher than the normal operating temperature, the $\mathrm{CH}_{4}$ is mainly produced. When the fault temperature rises, $\mathrm{C}_{2} \mathrm{H}_{4}$ and $\mathrm{C}_{2} \mathrm{H}_{6}$ gradually become the main characteristics. When the temperature is higher than 1000 degrees Celsius, the oil cracking contains more $\mathrm{C}_{2} \mathrm{H}_{2}$. If it is affected with damp or bubbles in the oil, it will contain more $\mathrm{H}_{2}$. If the fault involves solid insulation materials, it can produce more $\mathrm{CO}$ and $\mathrm{CO}_{2}{ }^{[2]}$. The gas composition of different fault types is shown in the Table 1.

Table 1 The gas composition of different fault types

\begin{tabular}{|c|c|c|c|}
\hline $\begin{array}{l}\text { Serial } \\
\text { number }\end{array}$ & Fault type & $\begin{array}{l}\text { The main gas } \\
\text { composition }\end{array}$ & $\begin{array}{c}\text { The secondary gas } \\
\text { composition }\end{array}$ \\
\hline 1 & Overheated oil & $\mathrm{CH}_{4} \mathrm{C}_{2} \mathrm{H}_{4}$ & $\mathrm{H}_{2} \mathrm{C}_{2} \mathrm{H}_{6}$ \\
\hline 2 & Overheated oil and paper & $\mathrm{CH}_{4} \mathrm{C}_{2} \mathrm{H}_{4} \mathrm{CO} \mathrm{CO}_{2}$ & $\mathrm{H}_{2} \mathrm{C}_{2} \mathrm{H}_{6}$ \\
\hline 3 & $\begin{array}{l}\text { Partial discharge in oil } \\
\text { paper insulation }\end{array}$ & $\mathrm{H}_{2} \mathrm{CH}_{4} \mathrm{C}_{2} \mathrm{H}_{4} \mathrm{CO}$ & $\mathrm{C}_{2} \mathrm{H}_{6} \mathrm{CO}_{2}$ \\
\hline 4 & $\begin{array}{l}\text { Spark discharge in } \\
\text { transformer oil }\end{array}$ & $\mathrm{H}_{2} \mathrm{C}_{2} \mathrm{H}_{2}$ & \\
\hline 5 & Arc in the oil & $\mathrm{H}_{2} \mathrm{C}_{2} \mathrm{H}_{2}$ & $\mathrm{CH}_{4} \mathrm{C}_{2} \mathrm{H}_{4} \mathrm{C}_{2} \mathrm{H}_{6}$ \\
\hline 6 & Arc in the oil and paper & $\mathrm{H}_{2} \mathrm{C}_{2} \mathrm{H}_{2} \mathrm{CO} \mathrm{CO} 2$ & $\mathrm{CH}_{4} \mathrm{C}_{2} \mathrm{H}_{4} \mathrm{C}_{2} \mathrm{H}_{6}$ \\
\hline 7 & $\begin{array}{l}\text { Be affected with damp or } \\
\text { oil bubble }\end{array}$ & $\mathrm{H}_{2}$ & \\
\hline
\end{tabular}

The above chart is qualitative description and it can not quantify the gas. The table below can be used to determine fault properties. 
Table 2 Fault property and the characteristics of characteristic gas

\begin{tabular}{|c|c|c|c|}
\hline $\begin{array}{c}\text { Serial } \\
\text { number }\end{array}$ & Fault property & $\begin{array}{c}\text { Main } \\
\text { ingredients }\end{array}$ & The characteristics of characteristic gas \\
\hline 1 & $\begin{array}{l}\text { Overheating } \\
\text { fault in general }\end{array}$ & $\mathrm{CH}_{4} \mathrm{C}_{2} \mathrm{H}_{4}$ & High total hydrocarbon, $\mathrm{C}_{2} \mathrm{H}_{2}<5 \mathrm{ppm}$ \\
\hline 2 & $\begin{array}{l}\text { Serious } \\
\text { overheating fault }\end{array}$ & $\mathrm{CH}_{4} \mathrm{C}_{2} \mathrm{H}_{4}$ & $\begin{array}{l}\text { High total hydrocarbon, } \mathrm{C}_{2} \mathrm{H}_{2}>5 \mathrm{ppm} \text {, but } \\
\text { it did not constitute major component of } \\
\text { total hydrocarbon, } \mathrm{H}_{2} \text { is higher. }\end{array}$ \\
\hline 3 & Partial discharge & $\mathrm{H}_{2} \mathrm{CH}_{4}$ & $\begin{array}{l}\text { Total hydrocarbon is not high, } \mathrm{H}_{2}>100 \\
\mathrm{ppm}, \mathrm{CH}_{4} \text { constitutes the main } \\
\text { components of the total hydrocarbon. }\end{array}$ \\
\hline 4 & Spark discharge & $\mathrm{H}_{2}$ & $\begin{array}{l}\text { Total hydrocarbon is not high, } \mathrm{C}_{2} \mathrm{H}_{2}>10 \\
\mathrm{ppm}, \mathrm{H}_{2} \text { is higher. }\end{array}$ \\
\hline 5 & Arc discharge & $\mathrm{H}_{2} \mathrm{C}_{2} \mathrm{H}_{2}$ & $\begin{array}{l}\text { High total hydrocarbon, } \mathrm{C}_{2} \mathrm{H}_{2} \text { is high and } \\
\text { constitutes major component of total } \\
\text { hydrocarbon, } \mathrm{H}_{2} \text { is high. }\end{array}$ \\
\hline
\end{tabular}

The quantitative conditions of various kinds of gas are shown above when five kinds of fault occur. However, these quantitative expressions are not very accurate. In order to be able to more effectively and accurately diagnose the transformer fault, this paper uses BP neural network to identify fault, in order to improve the accuracy of fault diagnosis.

\section{Transformer Fault Diagnosis Based on BP Neural Network}

Back Propagation Neural Network. BP (Back Propagation) neural network is a kind of learning algorithm with error Back Propagation. It is the multilayer feed forward network that composed of input layer, one or more of the hidden layers and output layer of. Assuming that has the number of processing units on each floor is $\mathrm{N}$, the number of mode training set contains sample is $\mathrm{M}$ in the $\mathrm{BP}$ network.

In the first, a learning sample $\mathrm{p}(\mathrm{p}=1,2, \ldots, \mathrm{M})$, node $\mathrm{j}$ remember to input combined net $_{p j}$, for

output $O_{p j}$, then $n e t_{p j}=\sum_{i=1}^{N} W_{j i} O_{p i}, O_{p j}=f\left(\right.$ net $\left._{p j}\right)$

If we set arbitrary number as the initial weights, , its network error between the output and the desired output $\left(d_{p j}\right)$ to each input sample p as follows:

$E=\sum_{p} E_{p}=\left[\sum_{j}\left(d_{p j}-O_{p j}\right)^{2}\right] / 2$.

BP network with hidden and the output layer unit of the error of calculation is different. BP network has a weight correction formula is:

$\mathrm{W}_{\mathrm{ji}}=\mathrm{W}_{\mathrm{ji}}(t)+\eta \delta_{\mathrm{pj}} O_{\mathrm{pj}}$

$\delta_{\mathrm{pj}}$ for input and output nodes is different, the output node is $\delta_{\mathrm{pj}}=f^{\prime}\left(\right.$ net $\left._{\mathrm{pj}}\right)\left(d_{\mathrm{pj}}-O_{\mathrm{pj}}\right)$, for input nodes is $\delta_{\mathrm{pj}}=f^{\prime}\left(\right.$ net $\left._{\mathrm{pj}}\right) \sum_{\mathrm{k}} \delta_{\mathrm{pk}} \mathrm{W}_{\mathrm{kj}}$. The $\eta$ is the learning rate. Usually, a weight correction formula still need to adding inertial parameters of $\alpha$, which are: 
$\mathrm{W}_{\mathrm{ji}}=\mathrm{W}_{\mathrm{ji}}(t)+\eta \delta_{\mathrm{pj}} O_{\mathrm{pj}}+\alpha\left(\mathrm{W}_{\mathrm{ji}}(t)-\mathrm{W}_{\mathrm{ji}}(t-1)\right)$

The learning process of BP algorithm is composed of forward and reverse transmission. In forward propagation, the input information from the input layer through the hidden layer can handle step by step, and then to output layer. If we want not get the desired output, the output layer will return into the back propagation and the error signal will be back. By modifying the weights of each neuron, we hope the error signal is minimal. Through ongoing positive and reverse transmission, eventually we make the network output values and expectations converge. The trained BP network can work for transformer fault diagnosis [3-5].

The Process Based on BP Neural Network. We can judge the latent fault about transformer by some kinds of gases, the main ones: hydrogen $\left(\mathrm{H}_{2}\right)$, methane $\left(\mathrm{CH}_{4}\right)$, ethane $\left(\mathrm{C}_{2} \mathrm{H}_{6}\right)$, ethylene $\left(\mathrm{C}_{2} \mathrm{H}_{4}\right)$, acetylene $\left(\mathrm{C}_{2} \mathrm{H}_{2}\right)$, carbon monoxide $(\mathrm{CO})$, carbon dioxide $\left(\mathrm{CO}_{2}\right)$. We use the content of 7 kinds of gas as the input end of the BP neural network. The fault of transformer is classified 7 kinds in the paper, they are: oil overheating, oil and paper overheating, partial discharge in oil paper insulation, spark discharge in oil, oil in the arc, oil and arc in the paper, and affected with damp or any air bubbles in oil. According to the seven kinds of fault types, the paper will be set up the expectations of the BP neural network output. Settings as shown in table 3. Input layer node number is 7, number of hidden layer nodes is 12, and the number of BP neural network nodes in the output layer is 4 . Firstly, we need get enough samples for training, after that, the completion of other data for diagnosis.

Table 3 The Expectations of the BP Neural Network Output Settings

\begin{tabular}{ccc}
\hline Serial Number & Fault Type & Expected Output \\
\hline 1 & oil overheating & $(0.9,0.1,0.1,0.1)$ \\
2 & oil and paper overheating & $(0.1,0.9,0.1,0.1)$ \\
3 & partial discharge in oil paper insulation & $(0.1,0.1,0.9,0.1)$ \\
4 & spark discharge in oil & $(0.1,0.1,0.1,0.9)$ \\
5 & oil in the arc & $(0.9,0.9,0.1,0.1)$ \\
6 & oil and arc in the paper & $(0.1,0.9,0.9,0.1)$ \\
7 & affected with damp or any air bubbles & $(0.1,0.1,0.9,0.9)$ \\
\hline
\end{tabular}

\section{Numerical Example}

The Training Process. To collect 200 samples as training samples of BP neural network. The times of neural network training iterations are 1000, in the process, the error is 0.0001 , and the learning speed is 0.1 . After learning, network fully identifies the learning samples, and gives neural network training.

The Diagnostic Process. In this part, we do the online monitoring of transformer. The result shows that there are 7 kinds of gases. The content of the seven kinds of gas look as the training of the neural network input, to diagnosis. And then we get the final result is: $(0.0952,0.0930,0.0920$, 0.9066), that the type of the transformer failure to spark discharge in transformer oil.

\section{Summary}

The means of scientific monitoring and fault diagnosis which is adopted for electrical equipment maintenance can effectively improve the reliability of electrical equipment and reduce the cost of operation and maintenance. Transformer is the most important equipment in power transmission and transformation system and its operation reliability directly affects the safety of the power system, the operation cost and economic benefit, therefore in this paper the online monitoring and fault diagnosis 
of transformer are studied. This paper establishes gas online monitoring system from transformer oil and uses BP neural network to improve transformer fault diagnosis method (characteristic gas method). By gas online monitoring of transformer oil, and then the numerical example verifies the effectiveness of the improved diagnostic method.

\section{References}

[1] Xin Wang: On-line Monitoring and Fault Diagnosis Analysis about the Electrical Equipment, (Shandong University, China 2005).

[2] Yingzi Li: On-line Monitoring and Fault Diagnosis Analysis about the Electrical Equipment Based on the Fuzzy Mathematic Theory (Fuzhou University, China 2003).

[3] Caihong Liu, in: Research of BP Neural Network Learning Algorithm, (Chongqing Normal University, China 2008)

[4] X Zhao, XJ Wen, HH Zhao: Combination Method of Principal Component Analysis and Support Vector Machine for On-line Process Monitoring and Fault Diagnosis: submitted to Journal of DongHua University (2011).

[5] J Chen, YY Chen. Electrical Equipment Infrared On-line Monitoring and Fault Diagnosis Management Research: submitted toJournal of Anhui Electrical Engineering Professional Technique College (2013).

[6] X Gan, L Chen, D Yang, G Liu, The research of rainfall prediction models based on Matlab neural network: submitted to IEEE International Conference on Cloud Computing \& Intelligence Systems (2011).

[7] Y Zhao: Research and Application on BP Neural Network Algorithm: submitted to International Industrial Informatics \& Computer Engineering Conference (2015). 